\title{
JPEB
}

Jurnal Penelitian Ekonomi dan Bisnis, 5 (1), 2020, Hal: 90 - 102

http://www.jpeb.dinus.ac.id

\section{DETERMINAN FINANCIAL DISTRESS DENGAN PROFITABILITAS SEBAGAI VARIABEL MODERASI}

\author{
Risma Wilujeng $^{1 *}$ dan Agung Yulianto ${ }^{2}$ \\ 1,2Jurusan Akuntansi, Fakultas Ekonomi, Universitas Negeri Semarang \\ Kampus Sekaran, Gunung Pati, Semarang, Indonesia \\ *Corresponding Author: rismawe@gmail.com
}

Diterima: Oktober 2019; Direvisi: Januari 2020; Dipublikasikan: Maret 2020

\begin{abstract}
The purpose is to anlyze and describe the effects of leverage, market ratios, institusional ownership, audit commitees, and the effect of profitability moderation on financial distress. Population in this study food and baverage company listed on the Stock Exchange in 2013-2017. The research uses apurposive sampling method of 90 units analysis. The analytical method used is logistic regression and absolute value difference test. The results are leverage, market ratios, institutional ownership, audit committees, and market ratios, institutional ownership, audit committees that are moderated by profitability have no effect in financial distress. While leverage moderated by the effect of financial distress. The conclusion is, profitability moderates the effect of leverage on financial distess. Suggestions for further research are excepted to be able to use other company sectors, for example the property and real estate sector because in this study not many companies experience financial distress.
\end{abstract}

Keyword : Financial Distress Keywords: Financial Distress; Laverage; Market Ratio; Corporate Governance; Profitability.

\begin{abstract}
ABSTRAK
Tujuan Tujuan dari penelitian ini yaitu menganalisis dan mendeskripsikan pengaruh laverage, rasio pasar, kepemilikan institusi, komite audit, dan pengaruh dari moderasi profitabilitas terhdap financial distress. Populasi penelitian yaitu perusahaan food and beverage yang terdaftar di BEI tahun 2013. Sampel yang digunakan metode purposive sampling sejumlah 90 unitanalisis. Metode analisis yang digunakan yaitu regresi logistic dan uji selisih mutlak Hasil penelitian yaitu laverage, rasio pasar, kepemilikan institusioal, komite audit yang dimoderasi profitabilitas ridak berpengaruh terhadap financial distress Sedangkan laverage yang dimoderasi oleh profitabilitas berpengaruh terhadap fianancial distress. Simpulan dari penelitian yaitu profitabilitas mempoderasi pengrauh leverage terhadap fianancial distress. Saran untuk peneliti berikutya dihrapkan menggunakan sektopr lain seperti sector property dan real estate, karena ini tidak banyak perusahaan yang mengalami financial distress.
\end{abstract}

Kata Kunci: Financial Distress; Laverage; Rasio Pasasr; Corporate Governance; Profitabilitas 


\section{PENDAHULUAN}

Berdirinya sebuah perusahaan tentunya memiliki tujuan tertentu salah satunya yaitu untuk memperoleh keuntungan atau profit oriented. Dalam menjalankan bisnisnya tentu perusahaan akan mengharapkan perolahan keuntungan atau laba yang tinggi agar perusahaan mampu bertahan dan memiliki daya saing sesuai dengan visi dan misi sehingga perusahaan tersebut memiliki kinerja perusahaan yang baik. Kondisi kinerja perusahaan yang baik merupakan dambaan bagi setiap pemegang saham yang nantinya dapat menarik investor atau calon investor untuk menanamkan investasinya ke perusahaan tersebut. Namun dalam kenyatannya, tidak semua harapan yang dicita citakan oleh perusahaan itu akan tercapai, hal ini dapat disebabkan oleh beberapa kendala atau hambatan yang dapat menyebabkan perusahaan memiliki potensi kebangkrutan.

Financial distress merupakan suatu proses menurunnya posisi financial perusahaan yang dialami perusahaan sebelum perusahaan tersebut bangkrut ataupun mengalami likuidasi (Platt \& Platt, 2002). Menurut Simanjuntak, Titik, \& Aminah (2017) kondisi financial distress merupakan kondisi dimana terjadi penurunan keuangan sebelum perusahaan tersebut bangkrut. Brahmana (2006) mengatakan bahwa Financial distress akan terjadi ketika perusahaan tidak dapat menjaga kestabilan keuangannya sehingga akan menimbulkan kerugian opersional dan kerugian bersih tahun berjalan. Apabila hal ini tidak diakukan perbaikan dan terjadi selama 2 tahun bertutr turut, maka perushaan dapat menuju kearah kebangkrutan. Financial distress dapat terjadi karena dua faktor utama yaitu faktor internal dan eksternal, faktor internal diantaranya merupakan faktor ekonomi, faktor keuangan, dan corporate governance. Sedangkan faktor eksternal yang mempengaruhi financial distress yaitu umur dan ukuran serta tingkat pertumbuhan (Septivani \& Agoes, 2014). Whitaker (1999) menyatakan financial distress terjadi karena adanya economic distress, yaitu penurunan dalam industri perusahaan dan manajemen perusahaan yang buruk.

Faktor lain selain factor keuangan yang yang dapat mempengaruhi financial distress yaitu corporate governance yang ada di dalam perusahaan (Hanifah \& Purwanto, 2013). Corporate governance dapat diartikan sebagai sistem yang mengatur dan mengendalikan perusahaan yang menciptakan nilai tambah atau value added untuk semua stakeholder (Monks dan Minow, 2011 dalam Septivani \& Agoes, 2014). Tujuan dari adanya corporate governance yaitu untuk menciptakan nilai tambah yang diperuntukan bagi pihak yang berkepentingan,sehingga agency cost dapat diminimalisir (Bodroastuti,2009).

Dalam satu tahun terahir ini berdasarkan informasi yang diperoleh dari (https://ekonomi.kompas.com/ 2 Febuari 2019). Selain itu dilansir dari (https://nasional.kontan.co.id/2 Febuari 2019). Pengadilan Niaga Jakarta Pusat, resmi menyatakan status pailit kepada PT. Sariwangi (SAEA) dan PT. Maskapai Perkebunan Indorub Sumber Wadung, yang merupakan perusahaan perkebunan teh pada 16 Oktober 2010. Putusan tersebut dijatuhkan atas dasar bahwa PT. SAEA dan Indorub lalai dalam memenuhi kewajibannya. Mengetahui hal tersebut, PT. Unilever sebagai pemegang brand Sariwangi yang melalukan akuisis pada tahun 1989, pada ahirnya memutuskan kerjasama dengan PT. SAEA.

PT. Nyonya Meneer pun juga menutup pabriknya yang berada di Semarang, lantaran bangkrut dan tidak mampu membayar hutang sebesar 267 miliar kepada sejumlah investor. Selain terlilit hutang Nyonya Meneer sebelumnya pernah mengalami krisis operasional yang cukup panjang, dari tahun 1984 hingga tahun 2000, hal tersebut terjadi karena sengketa perebutan kekuasaan antar keluarga (https://ekonomi.kompas.com 2 Febuari 2019).

Maka dari itu diperlukan adanya sarana untuk mengidentifikasi terjadinya kesulitan keuangan sejak awal atau sebuah peringatan dini (early warning system). Agency Theory memberikan penjelasan bahwa model peringan dini (early waring system) merupakan hal yang sangat penting bagi pihak manajemen dalam pengambilan keputusan untuk meminimalisir timbulnya permasalahan keuangan yang dapat menyebabkan terjadinya kondisi terjadinya financial distress.

Peneliti yang sudah melakukan reasrch mengenai factor internal yang dapat mempengaruhi financial distress diantarya yaitu (Widhiari dan Merkusiwati, 2015) melaukan 
penelitian tentang pengaruh likuiditas, operating capacity, sales growth, dan leverage terhadap financial distress. (Hidayat dan Meiranto, 2014) melalukan penelitian pengaruh leverage, likuiditas, aktivitas dan profitabilitas dengan firm zise sebagai variabel kontrol. Peneliti lainnya yang meneliti tentang financial distress yaitu Andre (2013) tentang pengaruh leverage, likuiditas, rasio aktivitas dan profitabilitas. Curry dan Banjarnahor (2018) juga melakukan penelitian pengaruh likuiditas, profitabilias, financial leverage, pertumbuhan penjualan dan rasio pasar. Beberapa peniliti juga melakukan penelitian terhadap factor nonkeuangan yang mempengaruhi financial distess diantaranya adalah Fathonah (2016) yang meneliti tentang pengaruh kepemilikan institusional, kepemilikan manajerial, komposisi dewan komisaris, dan komite audit terhadap financial distress. (Helena \& Saifi, 2016) meneliti pengaruh dewan direksi, proporsi komisaris independen, komite audit dan kepemilikan institusional.

Leverage merupakan suatu indicator yang menunjukkan kemampuan perusahaan dalam memenuhi kewajibannya baik kewajiban jangk apnjang maupun jangka (Widarjo dan Seiawan, 2009). Hasil dari penelitian yang dialukan Lisiantara, dan Febriana (2018) menunjukkan bahwa leverage memiliki pengaruh positif terhadap financial distress, sedangkan penelitian yang dilakukan Curry dan Banjarnahor (2018) menyatakan bahwa leverage memiliki pengaruh negative terhdap financial distress.

Rasio pasar merupakan kemampuan perusahaan dalam menciptakan nilai terutama pada pemegang saham dan calon investor (Curry dan Banjarnahor, 2018). Yudadibrata \& Soenarno (2016) menyatakan bahwa rasio pasar tidak memiliki pengaruh terhadap financial distress, sedangkan Curry dan Banjarnahore (2018) menyatakan bahwa penelitiannya memiliki hasil rasio pasar berpengaruh positif terhadap financial distress.

Kepemilikan institusional yaitu bagian dari mekanisme corporate governance dimana keberadaanya dapat menekan terjadinya konflik keagenanan atanra manager dengan pemilik (Hanifah dan Purwanto, 2013). Chinantya dan Merkusiwati (2015) menyatakan bahwa kepemilikan institusional tidak berpengaruh terhadap financial distress, sedangkan menurut hasil penelitian Fathonah (2016) menyatakan kepemilikan instituional berpengaruh negatif terhadap financial distress.

Menurut Ikatan Komite Audit meyatakan Komite Audit merupakan suatu komite yang berkerja secara profesional, dan independen yang keberadaanya dibentuk oleh dewan komisaris, maka dari itu tugas dari komite audit adalah untuk membantu dan memperkuat fungsi dewan komisaris dalam menjalankan fungsi pengawasan atas prose pelaporan keuangan, manajemen risiko, pelaksanaan audit dari implementasi corporate governance di perusahaan perusahaan. Hanifah dan Purwanto (2013) menyatakan bahwa jumlah anggota komite audit tidak berpengaruh terhadap financial distress. (Radifan dan Yuyetta (2015) menyatakan bahwa komite audit berpengaruh positif terhadap financial distress.

Tujuan penelitian ini yaitu untuk menganaisis dan mendiskripsikan pengaruh leverage, rasio pasar, kepemilikan institusional, dan komite audit terhadap financial distress dengan profitabilitas sebagai variabel pemoderasi. Hasil dari penelitian terdahulu masih inkonsisten sehingga penelitian mengenai financial distress menarik untuk diteliti kembali. Orisinilitas dari penelitian ini adalah menghadirkan Penambahan variabel inkonsisten berupa (variabel kepemilikan institusional dan rasio pasar), karena belum pernah diteliti secara bersama sama menggunakan variabel moderasi brupa variabel profitabilitas. Orisinalitas lain yang berkaitan yaitu pada penggunaan metode pengujian berupa uji nilai selisih mutlak.

\section{TINJAUAN PUSTAKA}

\section{Agency Theory}

Jensen \& Meckling (1976) menggambarkan hubungan kontrak antara pemilik perusahaan dengan dengan manajer, teori ini menyebabkan konfilik antara pemilik (principle) dan manajer (agent) karena adanya pemisahan kepemilikan dan pengelolaan atas perusahaan. Koflik ini akan 
terjadi ketika pihak masing masing sama sama ingin memaksimalkan kekayaan (Lisiantara dan Febrina, 2018).

\section{Signalling Theory}

Teori sinyal merupakan teori yang aamengemukakan tentang perusahaan dalam memberikan sinyal kepada pengguna laporan keuangan. Teori ini mengungkapan tentang bagaiamana seharusnya sinyal yang diberikan kepada pengguna laporan keuangan. Sinyal akan diberikan oleh perusahaan berdasarkan laporan tahunan, dimana laporan tersebut akan dimuat seacara terbuka dan transparan. Informasi yang disajikan di dalam laporan keauangan harus disajikan seacara relevan (Prasetyo \& Fachrurrozie, 2016).

\section{Pengembangan Hipotesis}

Leverage merupakan suatu indicator yang menunjukkan kemampuan perusahaan dalam memenuhi kewajibannya baik kewajiban jangka panjang maupun jangka (Widarjo dan Seiawan, 2009). Dalam hal ini perusahaan akan dilihat sejauh mana perusahaan akan bergantung pada utang untuk membiaya operasionalnya. Apabila perusahaan terlalu bergantung pada utang maka di masa mendatang akan menimbulkan permasalahan yaitu pelunasan pinjaman di tambah dengan bunga yang harus di tanggung oleh perusahaan. Jika perusahaan terlalu berantung pada hutang dalam operasionalnya, maka hal tersebut dapat menyebabkan risiko gagal bayar yang dapat membawa perusahaan ke dalam kondisi financial distress (Agusti, 2013). Hal tersebut sesuai dengan agency theory bahwa keputusan yang berikatan dengan hutang piutang berada di bawah kendali agen, apabila jumlah hutang yang jatuh tempo terlalu banyak maka perlu adanya koreksi terhadap agen. (Hidayat \& Meiranto, 2014). Penelitian ini sejalan dengan hasil penelitian Lisiantara, dan Febrina (2018), Hanifah \& Purwanto (2013) yang menyatakan bahwa leverage memiliki pengaruh positif terhadap financial distress.

$\mathrm{H}_{1} \quad$ : Leverage berpengaruh positif terhadap financial distress

Rasio Pasar (Market Ratio) atau rasio saham adalah rasio yang dapat digunakan untuk mengukur nilai saham. Rasio pasar merupakan salah satu informasi yang sangat bermanfaat, karena dapat memberi petunjuk bagi investor mengenai prospek perusahaan. Semakin baik hasil dari rasio ini, maka kemungkinan perushaan akan mengalami financial distress akan semakin kecil, begitu juga sebaliknya, jika rasio ini semakin kecil maka semakin besar peluang perusahan mengalami financial distress. Sesuai dengan Signalling theory yang lebih menekankan pada informasi yang diberikan perusahaan terhadap pihak Karena dapat memberikan good news atau bad news yang dapat menggambarkan prospek earning perusahaan dimasa depan, dan juga dapat menggambarkan kinerja kuangan perusahaan, untuk keperluan identifikasi prospek dan risiko dalam masa masa yang akan dating. Penelitian ini didukung oleh penelitian yang dilakukan (Curry \& Banjarnahor, 2018) yang menyatakan bahwa rasio pasar memiliki pengaruh negative terhadap financial distress.

$\mathrm{H}_{2} \quad$ : Rasio pasar berpengaruh negative terhadap financial ditress

Kepemilikan institusional yaitu bagian dari mekanisme corporate governance dimana keberadaanya dapat menekan terjadinya konflik keagenan antara manager dengan pemilik (Hanifah dan Purwanto, 2013). Agency theory menjelaskan bahwa dalam hubungan keagenan terdapat arah dan tujuan yang berbeda yang dapat menyebabkan konflik agency. Adanya pengawasan yang dilakukan oleh pihak institusi ini diharpakan dapat menekan terjadinya tidakan manajer yang akan menguntungkan pihaknya. Semakin banyaknya kepemilikan institusi dalam perusahaan, maka diharapakan akan semakian efisien manager dalam menggunakan aktiva yang ada, sehingga probabilitas perusahaan akan mengalami financial distress semakian rendah, begitu pula sebaliknya semakin rendah tingkat kepemilikan institusi maka akan semakian tinggi 
Risma Wilujeng dan Agung Yulianto : Determinan Financial Distress Dengan Profitabilitas Sebagai Variabel Moderasi

perusahaan mengalami ifinancial distress. Penelitian ini diperkuat oleh penelitian yang dilakuyikan oleh Fathonah (2016).

$\mathrm{H}_{3} \quad$ : Kepemilikan Institusional berpengaruh negative terhadap financial distress.

Komite audit merupakan komite yang memiliki fungsi dan peran untuk membantu tugas dan fungsi dari dewan komisaris, yang juga komite audit ini dibentuk oleh dewan komisaris. Berkaitan dengan tugasnya keefektifan komite audit sangat diperhatikan dan dipertimbangkan karena keefektifan komite audit dapat membantu meingkatkan kinerja keungan perusahaan sehingga dapat mengurangi risiko perusahaan dari financial distress (Putri \& Merkusiwati, 2014). Perusahaan dengan tingkat keefektifan komite audit yang tinggi akan meningkatkan kinerja dan menuntun manajemen pada pemilihan keputusan yang tepat sehingga perusahaan dapat menghindari kemungkinan terjadinya financial distress atau kesulitan keuangan. Hal ini sejalan dengan Agency theory menjelaskan bahwa dengan adanya corporate governance melalui komite audit, diharapkan dapat meminimalkan tindakan manajemen yang menyeleweng seperti memanipulasi laba perusahaan melalui pengawasan dan wewenang kontroling yang dimiliki oleh komite audit. Penelitian ini didukung oleh hasil penelitian yang dilakukan oleh Nuresa \& Hadiprajitno (2013) yang menunjukkan bahwa komite audit berpengaruh negative terhadap financial distress.

$\mathrm{H}_{4} \quad$ : Komite Audit berpengaruh negatuif terhadap financial distress

Rasio leverage merupakan kemampuan entitas dalam melunasi utang, baik utang jangka panjang maupun jangka pendek Apabila manajemen memaanfaatkan utang dalam intensitas yang besar untuk mendanai operasional perusahaan, maka dapat menimbulkan permasalahan dimasa depan tentang pelunasan pokok pinjaman dan bunga yang harus di tanggung.

Laba merupakan sebuah orientasi perusahaan didirikan sehingga dalam menjalankan kegiatan usahanya perusahaan akan sangat memperhatikan laba, karena dengan pencapain laba yang tinggi akan meningkatkan nilai perusahaan. Manajemen dapat memanfaatkan asset yang dimiliki agar dapat menghasilkan laba Hal ini sejalan dengan Agency Theory bahwa kegiatan operasional merupakan hal yang harus dilakukan oleh agent, apabila agent tepat dalam mengambil keputusan sehingga produk yang dihasilkan oleh perusahaan akan terjual dalam kapasitas tinggi sehingga laba yang diperoleh pun juga tinggi. Dari kemampuan perusahhan dalam mendapatkan laba yang maka akan mempengaruhi tingkat kemampuan perusahaan dalam membayar kewajibannnya terhadap pihak ketiga sehingga probabilitas kemungkinan perusahaan mengalami komdisi financial distress akan semakian kecil.

$\mathrm{H}_{5} \quad$ : profitabilitas memoderasi leverage terhadap financial ditress

Rasio Pasar (Market Ratio) atau rasio saham adalah rasio yang dapat digunakan untuk mengukur nilai saham. Rasio pasar merupakan suatu informasi yang mendasar bagi para investor akrena dapat memebrikan finyal good news atau bad news, yang dapat menggambarkan prospek earning perusahaan dimasa depan, dan juga dapat menggambarkan kinerja kuangan perusahaan, untuk keperluan identifikasi prospek dan risiko dalam masa masa yang akan datang

Sesuai dengan Agency Theory yang menyatakan, apabila profitbilitas yang dihasilkan oleh perusahaan tinggi maka akan mempengaruhi sikap manajemen dalam menghasilkan laba. Semakin tinggi profitabilitas yang dihasilkan oleh perusahaan maka hal tersebut akan menarik kreditor atau pihak lain untuk berinvestasi dalam perusahaan tersbut, yang dapat dilihat dari hasil EPS dan memperhatikan kualitas saham. Semakin tinggi laba yang diperoleh perusahaan maka perusahaan akan memeperoleh suntikan dana yang dapat mengurangi risiko financial distress.

$\mathrm{H}_{6} \quad$ : profitabilitas memoderasi rasio pasar terhadap financial distress

Kepemilikan institusional merupakan salah satu mekanisme corporate governance yang dapat mengurangi masalah dalam teori keagenan antara pemilik dan manajer sehingga timbul 
keselarasan kepentingan antara pemilik perusahaan dan manajer. rasio profitabilitas merupakan rasio yang menunjukkan hasil akhir dari sejumlah kebijakan dan keputusan seperti profit margin on sales, return on total assets dan lain sebagainya. Manajemen memiliki peran yang banyak dalam memperoleh keuntungan, sehingga hal tersebut dapat menimbulkan risiko yaitu manajemen akan mengambil keputusan yang lebih berpihak kepada kepentinganya sendiri. Sehingga dengan adanya kepemilikan institusi ini akan mencipatkan penggunaan asset yang lebih efektif dan mengurangi konflik keagenan yang terjadi sesuai dengan teori agensi, karena manajer atau agen akan bekerja diawasi langsung oleh institusi terkait, sehingga hal tersebut dapat meminimalkan perusahaan berada dalam kondisi financial distress.

$\mathrm{H}_{7} \quad$ : profitabilitas memoderasi kepemilikan institusional terhadap financial distress

Komite audit merupakan komite yang memiliki fungsi dan peran untuk membantu tugas dan fungsi dari dewan komisaris, yang juga komite audit ini dibentuk oleh dewan komisaris. Berkaitan dengan tugasnya keefektifan komite audit sangat diperhatikan dan dipertimbangkan karena keefektifan komite audit dapat membantu meningkatkan kinerja keungan perusahaan sehingga dapat mengurangi risiko perusahaan dari financial distress. (Putri \& Merkusiwati, 2014). Komite audit merupakan komite yang memiliki fungsi dan peran untuk membantu tugas dan fungsi dari dewan komisaris, yang juga komite audit ini dibentuk oleh dewan komisaris.

Berkaitan dengan tugasnya keefektifan komite audit sangat diperhatikan dan dipertimbangkan karena keefektifan komite audit dapat membantu meingkatkan kinerja keungan perusahaan sehingga dapat mengurangi risiko perusahaan dari financial distress. (Putri \& Merkusiwati, 2014).

Adanya profitabilitas yang tinggi ditunjang oleh keberadaan ukuran komite audit, karena komite audit memiliki peran untuk memahami laporan keuangan yang ada, sehingga kredibilitas penyusunan laporan keuangan dapat terjaga serta dapat mengurangi tindakan manajemen dalam memanipulasi laba perusahaan. Sesuai dengan agency theory dengan tingginya kompetensi yang dimiliki komite audit diharapkan dapat mengurangi masalah keagenan yang dapat menyebabkan risiko terjadinya financial distress.

$\mathrm{H}_{8} \quad$ : profitabilitas memoderasi komite audit terhadap financial distress

\section{METODE PENELITIAN}

Penelitian ini termasuk dalam penelitian kuantitatif dengan desain penelitian pengujian hipotesis yang dilakukan terhadap perusahaan food and beverage yang terdaftar di BEI tahun 2013-2017 dengan jumlah sempel sebanyak 23 perusahaan. Sampel diperoleh menggunakan metode purposive sampling sebanyak 18 perusahaan dengan periode pengamatan selama 5 tahun, sehingga unit analisisnya sebanyak 90 perusahaan. Penentuan sampel diperoleh dengan kriteria sebagai berikut:

Tabel 1. Kriteria Penentuan Sampel

\begin{tabular}{llcc}
\hline No. & \multicolumn{1}{c}{ Kriteria Sampel } & $\begin{array}{c}\text { Tidak } \\
\text { Masuk }\end{array}$ & $\begin{array}{c}\text { Kriteria } \\
\text { Masuk }\end{array}$ \\
\hline 1 & $\begin{array}{l}\text { Perusahan food and beverage yang terdaftar yang di BEI } \\
\text { periode 2013-2017 }\end{array}$ & 5 & 23 \\
2 & $\begin{array}{l}\text { Perusahaan sector food and bevergage yang menerbitkan } \\
\text { laporan keuangan selama 5 tahun berturut turut tahun }\end{array}$ & 18 \\
2013-2017 & $\begin{array}{c}\text { Perusahaan makanan dan minuman (food and beverage) } \\
\text { yang mempublikasikandata lengkap tahun 2013-2017 } \\
\text { berkaitan dengan variabel yang diteliti } \\
\text { Jumlah perusahaan sampel } \\
\text { Jumlah unit analisis ( 5 x 18 ) }\end{array}$ & 18 \\
\hline
\end{tabular}


Variabel dependen yang dignakan dalam penelitian ini yaitu financial distress. Sedangkan variabel independen yang digunakan dalam penelitian ini adalah leverage, rasio pasar, kepemilikan instutusional, komite audit dan profitabilitas sebagai variabel pemoderasi. Definisi operasional dalam penelitian disajikan dalam tabel berikut:

Tabel 2. Definisi Operasional Variabel Penelitian

\begin{tabular}{lcll}
\hline No & \multicolumn{1}{c}{ Variabel } & \multicolumn{1}{c}{ Definisi Variabel } & \multicolumn{1}{c}{ Indikator } \\
\hline 1. & Financial Distress & $\begin{array}{l}\text { Tahap penurunan kondisi keuangan } \\
\text { yang terjadi sebelum terjadinya } \\
\text { kebangkrutan ataupun likuidasi. }\end{array}$ & $\begin{array}{l}\text { EPS positif }=0 \\
\text { EPS negatif }=1\end{array}$ \\
2. Leverage & $\begin{array}{l}\text { Leverage merupakan rasio yang } \\
\text { digunakan untuk mengukur sejauh } \\
\text { mana aktiva perusahaan akan dibiayai } \\
\text { dengan hutang. }\end{array}$ & $\begin{array}{l}\text { Leverage }=\text { total liabilities } \\
\text { / total assets }\end{array}$ \\
& &
\end{tabular}

3. Rasio Pasar

Rasio yang digunakan untuk mengukur nilai saham.

EPS = Earning availabel for common stock / number of share of common

4. Kepemilikan
Institusional

5. Komite Audit

6. Profitabilitas salah satu mekanisme corporate governance yang dapat mengurangi konflik keagenan.

mekanisme corporate governance yang diharapkan mampu untuk mengurangi konflik keagenan dalam suatu perusahaan.
KI=jumlah saham yang
dimiliki oleh investor
institusional / jumlah
saham yang beredar

$K A=$ Frequensi

pertemuan komite audit
Kemampuan perusahaan dalam menghasilkan laba
ROA = Earnings after tax / total assets

Teknik pengumpulan data dalam penelitian ini menggunakan metode dokumentasi, dengan data berupa data sekunder meliputi laporan tahunan atau annual report perusahaan food and beverage yang terdaftar di BEI tahun 2013-2017. Metode analisis yang digunakan dalam penelitian ini adalah regresi logistik dan uji selisih nilai mutlak.

\section{HASIL DAN PEMBAHASAN}

Statistik deskriptif menggambarkan nilai rata-rata, maksimum, minimum, dan standar deviasi dari variabel Leverage, rasio pasar, kepemilikan institusional dan Komite audit, serta Profitabilitas. Namun dalam penelitian ini variabel financial distress merupakan variabel yang pengukurannya menggunakan skala nominal, jadi variabel financial distress tidak dapat diketahui nilai nilai rata-rata, maksimum,minimum, dan standar deviasi. Sehingga variabel ini hanya dapat dijelaskan dengan menggunakan tabel distribusi frekuensi dari unit analisisnya. Berikut tabel distribusi frekuensi variabel financial distress: 
Tabel 3. Distribusi Frekuensi Variabel Financial Distress

\begin{tabular}{clcccc}
\hline & Freq & Percent & $\begin{array}{c}\text { Valid } \\
\text { Percent }\end{array}$ & $\begin{array}{c}\text { Cumulative } \\
\text { Percent }\end{array}$ \\
\hline Valid & Non FD & 70 & 77.8 & 77.8 & 77.8 \\
& FD & 20 & 22.2 & 22.2 & 100.0 \\
& Total & 90 & 100.0 & 100.0 & \\
\hline
\end{tabular}

Dapat diketahui bahwa perusahaan yang terindikasi mengalami financial distress sebanyak 20 yang di beri nilai 1 , dengan persentase sebsesar $22.2 \%$. Sedangkan bahwa perusahaan yang sehat ditunjukkan dengan angka 0 memperoleh hasil sebanyak 70 perusahaan yang sehat dengan prosentase sebesar 77.8\%. Dapat diketahui bahwa dari 90unit analisis yang diteliti, 20 perusahaan terindikasi mengalami financial distress. Hal ini menunjukan bahwa perusahaan food and beverage yang terdaftar di Bursa Efek Indonesia (BEI) pada tahun 2013-2017 terdapat 22.2\% dari $100 \%$ perusahaan yang mengalami financial distress, diantaranya yaitu PT. Bintang Mitra Semestaraya Tbk tahun 2013, 2014, 2015, 2016 dan 2017, kemudian PT. Bumi Tekhnokultura Unggul Tbk pada tahun 2014, 2015, 2017. PT. Tri Bayan Tirta Tbk pada tahun 2015, 2016, 2017. PT. Prashida Aneka Niaga Tbk tahun 2015 dan 2016. PT. Budi Starch and Sweetener Tbk tahun 2016, dan PT. Tiga Pilar Sejahtera Food Tbk pada tahun 2016, sedangkan sisanya 77.8\% perusahaan yang tidak mengalami financial distress. Perusahaan perusahaan yang termasuk dalam kondisi financial distress tersebut meupakan perusahaan yang memiliki EPS negatif sehingga termasuk dalam kategori 1 yaitu kategori financial distress.

Variabel leverage, rasio pasar, kepemilkan institusional, komite audit dan profitabilitas ini dapat ditentukan nilai maksimum, minimum, rata-rata (mean), serta standar deviasinya. Oleh karena itu untuk mendeskripsikan variabel ini dapat menggunakan analisis ststistik deskriptif yang disajikan pada Tabel 4. berikut:

$\begin{aligned} & \text { Tabel 4. Analisis Statistik Deskriptif Leverage, Rasio Pasar, Kepemilkan } \\
& \text { Institusional dan Komite Audit }\end{aligned}$
\begin{tabular}{lccccc}
\multicolumn{7}{c}{ N } & Min & Max & Mean & St. Dev \\
\hline Lev & 90 & .05 & .96 & .4865 & .17746 \\
RP & 90 & -171.47 & 1364.00 & 1136.3251 & 6326.58056 \\
KI & 90 & .00 & 1.00 & .6912 & .25430 \\
KA & 90 & 2.00 & 12.00 & 4.9556 & 1.77948 \\
ROA & 90 & -.34 & .88 & .0919 & .14635 \\
Valid N & 90 & & & & \\
(listwise) & & & & & \\
\hline
\end{tabular}

Berdasarkan analisis statistik deskriptif tabel 4.2, diperoleh nilai minimal sebesar 0.05 yang dimiliki oleh PT Bintang Mitra Semestaraya Tbk pada tahun 2013. Sedangkan nilai maksimum sebesar 0.96 dimiliki oleh PT Multi Bintang Indonesia Tbk, pada tahun 2017 serta diperoleh nilai rata-rata (mean) sebesar 0.4865 dan standar deviasi sebesar 0.17746. Nilai rata-rata (mean) tersebut lebih besar dari nilai standar deviasi sehingga dapat disimpulkan data variable yang diperoleh tidak jauh berbeda, sehingga persebaran datanya menjadi kecil common stoct dibagi dengan number for share of common stoct dekali 1,00. Berdasarkan analisis statistic dekkriptif pada tabel 4, diperoleh nilai minimal sebesar -171.47 yaitu pada PT Tiga Pilar Sejahtera Food Tbk (AISA) pada tahun 2017. Sedangkan nilai maksimumnya sebesar 136.00 dimiliki oleh PT Mayora Indah Tbk (MYOR) pada tahun 2015, serta diperoleh nilai rata rata atau mean sebesar 139.7111 dan standar deviasi dengan nilai sebesar 232.26589. Dapat diketahui bahwa nilai mean lebih kecil daripada standar deviasai, sehingga dapat disimpulkan bahwa data sampel untuk variasi ini tergolong berbeda, sehingga sebaran datanya menjadi kecil. Berdasartkan analisis deskriptif untuk 
Risma Wilujeng dan Agung Yulianto : Determinan Financial Distress Dengan Profitabilitas Sebagai Variabel Moderasi

kepemilikan institusional, diperoleh nilai minimal 0.00, yang dimiliki oleh Industri Jamu dan farmasi Sidomuncul (SIDO) tahun 2013. Sedangkan untuk nilai maksimalnya dimiliki oleh PT Delta Djakarta Tbk (DLTA) pada tahun 2013 dengan nilai sebesar 1.00. Untuk nuilai rata rata sendiri diperoleh sebesar 0.6912, serta nilai standar deviasinya sebesar 0.25430 . dapat disimpulkan bahwa nilai mean lebih kecil dari standar deviasi, sehingga persebaran datanya kecil. Untuk komite audit diperoleh nilai minimal sebesar 2 yang dimiliki oleh PT Ultrajaya Milk Industri And Trading Company Tbk (ULTJ) pada tahun 2013. Sedangkan untuk nilai minimalnya diperoleh nilai sebesar 12 yang dimiloiki olej PT Bumi Teknokultura Unggul (BTEK) pada tahun 2013. Untuk nilai mean sendiri sebesar 4.9556, dan nilai standar deviasinya sebesar 1.77948. Nilai mean lebih besar dari standar deviasi, sehingga persebaran datanya manjadi besar. Hasil dari statistic deskriptif untuk profitabilitas sendiri diperoleh nilai minimal sebesar -0.34 yang dimiliki oelh PT Bintang Mitra Semestaraya Tbk (BMSR) pada tahun 2014, sedangkan untuk nilai maksimalnya sebesar 0.88 yang dimilki oleh PT Multi Bintang Indonesia Tbk (mLBI) pada tahun 2017. Nilai rata rata variable profitabiliotas menunjukkan angka sebesar 0.0919 , dan nilai standar deviasinya sebesar 0.14635 , sehiungga dapat disimpulkan bahwa nilai mean lebih kecil daripada nilai standar deviasi, sehingga persebran datanya menjadi kecil.

Analisis statistik inferensial yang digunakan untuk menguji hipotesis dalam penelitian ini adalah analisis multivariate dengan regresi logistik (logistic regretion). Regresi logistik digunakan untuk mengukur kekuatan pengaruh antara dua variabel atau lebih serta menunjukkan arah hubungan antara variabel independen dengan variabel dependen. Dengan regresi logistic ini tidak diperlukan pengujian asumsi normalitas, heterokedastitas, dan uji autokorelasi karena di dalam pengujian ini variabel terikat merupakan variabel dummy (0 dan 1). Hasil penelitian menunjukkan bahwa nilai -2 Log Likelihood (LL) pada step 0 awal dan step 1 mengalami penurunan sebesar 61,861. Hasil ini merupakan selisih dari - 2LL step 0 sebesar 95,347 dengan -2LL step 1 sebesar 33,486 . Penurunan ini menunjukkan model regresi tersebut baik atau dengan kata lain model regresi tersebut fit.

Berdasarkan pengujian Hosmer and Lemeshow Goodness-of-fit diketahui bahwa nilai nilai Chi-Square sebesar 1.253 dengan signifikan yang diperoleh sebesar 0,996. Nilai signifikan tersebut lebih besar dari 0,05 maka hipotesis diterima yang berarti tidak ada perbedaan antara model dengan. Hal tersebut menunjukkan bahwa tidak adanya perbedaan antara model dengan data empiris penelitina dan model regresi layak untuk digunakan dalam analsis berikutnya. Pengujian dari koefisien determinasi atau R2 menunjukkan bahwa diperoleh nilai dari Cox dan Snell's $R 2$ sebesar 0,497. Sedangkan nilai 0,761 merupakan nilai dari Nagelkerke's $R$ Square. Berdasarkan nilai tersebut dapat disimpulkan sebesar $76,1 \%$ variabilitas pada variabel dependen mampu dijelaskan oleh variabel independen. Sedangkan $23,9 \%$ sisanya dijelaskan melalui variabel-variabel lain diluar model penelitian.

Berdasarkan hasil yang diperoleh melalui matriks klrarifikasi dapat diprediksi sebanyak 14 perusahaan kemungkinan mengalami fianancial distress dari total 20 perusahaan yang mengalami financial distress. Sedangkan kekauatan model regresi dapat memprediksi probabilitas perusahaan yang tidak mengalami financial distress sebesar $95.7 \%$ yaitu terdapat 67 perusahaan dari total 70 perusahaan. Sedangakn untuk keseluruhan kekuatan prediksi dari model regresi dalam penelitian ini adalah sebesar $90.0 \%$.

Hasil uji multikolinieritas memnunjukkan bahwa tidak ditemukan adanya gejala multikolinieritas antar variable indepen. Hal tersebut ditunjukkan melalui hasil korelasi lebih dari 0,90 . Berdasarkan hasil tersebut, regresi logistic untuk variable independen tidak terdapat gejala multikolinieritas

Model regresi logistic yang digunakan dalam penelitian ini dapat dirumuskan sebagai berikut:

$$
\begin{aligned}
\text { Financial Distress }= & -9.356+(-2.029) \mathrm{LEV}+(-1.565) \mathrm{RP}+1.418 \mathrm{KI}+(-0.41) \mathrm{KA}-(-8.961) \\
& \mathrm{ROA}-3.867 \mathrm{SNM} 1-(-0.101) \mathrm{SNM} 2-(-0.067) \mathrm{SNM}+(0.16) \mathrm{SNM} \\
& 4+e
\end{aligned}
$$


Berikut ini merupakan ringkasan penelitian dari pengujian hipotesis yang dilakukan pada tabel 3 adalah sebagai berikut:

Tabel 5. Ringkasan Hasil Pengujian Hipotesis

\begin{tabular}{clcccc}
\hline Hipotesis & Koefisien & $\boldsymbol{\alpha}$ & Sig. & Hasil \\
\hline H1 & $\begin{array}{l}\text { Leverage berpengaruh positif terhadap } \\
\text { financial }\end{array}$ & -2.029 & 0.05 & 0.047 & Ditolak \\
R2 & $\begin{array}{l}\text { Rasio Pasar berpengaruh negative } \\
\text { terhadap financial distress }\end{array}$ & -1.565 & 0.05 & 0.144 & Ditolak \\
Kepemilikan Institusional berpengaruh & 1.418 & 0.05 & 0,043 & Ditolak \\
H4 & $\begin{array}{l}\text { negative terhadap financial distress } \\
\text { Komite Audit berpengaruh negative } \\
\text { terhadap financial distress }\end{array}$ & -0.041 & 0.05 & 0.973 & Ditolak \\
& $\begin{array}{l}\text { Leverage berpengaruh terhadap } \\
\text { financial distress dimoderasi oleh } \\
\text { profitabilitas }\end{array}$ & 3.867 & 0.05 & 0,006 & Diterima \\
Rasio Pasar berpengaruh terhadap & $\begin{array}{l}\text { fianancial distress dimoderasi oleh } \\
\text { profitablitas }\end{array}$ & -0.101 & 0.05 & 0.914 & Ditolak \\
Kepemilikan Institusional berpengaruh \\
terhadap financial distress dimoderasi \\
oleh profitabilitas
\end{tabular}

\section{Pengaruh Leverage terhadap Financial Distress}

Hasil penelitian berdasarkan tabel 3 menunjukkan $\mathrm{H} 1$ yang menyatakan leverage berpengaruh positif terhadap prediksi financial distress ditolak. Sehingga dapat dinyatakan bahwa banyaknya hutang yang dimiliki oleh perusahaan kemungkinan akan menunrunkan tingkat perusahaan dalam mengalami kondisi financial distress, hal tersebut dapat terjadi. Perusahaan yang menjadi unit analisis cenderung memiliki tingkat pendapatan laba diatas rata rata, yang berarti bahwa hasil dari operasional perusahaan dan keputusan manager dalam menghasilkan laba tepat sehingga hutang hutang yang ada dapat ditutup dengan laba yang dhasilkan oleh perusahaan.

Hasil penelitian ini tidak sesuai dengan agency theory yang menyatakan bahwa keputusan yang berikatan dengan hutang piutang berada di bawah kendali agen, apabila jumlah hutang yang jatuh tempo terlalu banyak maka perlu adanya koreksi terhadap agen (Hidayat \& Meiranto, 2014). Hasil penelitian ini sejalan dengan penenlitian yang dilakukan oleh Widhiari \& Merkusiwati (2015) serta Putri \& Merkusiwati (2014) yang menyatakan bahwa leverage tidak berpengaruh terhadap financial distress.

\section{Pengaruh Rasio Pasar terhadap Financial Distress}

Hasil penelitian berdasarkan tabel 3 menunjukkan $\mathrm{H} 2$ yang menyatakan rasio pasar berpengaruh negatif terhadap prediksi financial distress ditolak. Sehingga dapat dinyatakan bahwa dari EPS tinggi yang diterbitkan oleh perusahaan belum mampu mengurangi probabilitas perusahaan mengalami kondisi financial distress, hal tersebut mungkin terjadi karena indikator EPS belum cukup untuk merefleksikan kondisi keuangan sesungguhnya suatu perusahaan. Dari hasil data frekuensi distributif terlihat bahwa sedikit perusahaan yang memiliki EPS tinggi, dan sebagaian besar berada dalam kategori sedang. Hasil penelitian ini tidak sejalan dengan penelitian 
Risma Wilujeng dan Agung Yulianto : Determinan Financial Distress Dengan Profitabilitas Sebagai Variabel Moderasi

yang dilakukan oleh Curry \& Banjarnahor (2018) yang menyatakan bahwa rasio pasar memiliki pengaruh positif terhadap financial distress.

\section{Pengaruh Kepemilikan Institusional terhadap Financial Distress}

Hasil penelitian berdasarkan tabel 3 menunjukkan H3 yang menyatakan kepemilikan institusional tidak berpengaruh negatif terhadap prediksi financial distress ditolak. Sehingga hal tersebut tidak sejalan dengan teori yang digunakan yaitu agency theoy yang menyatakan bahwa adanya kepemilikan institusi dapat mengurangi tingkat perusahaan akan mengalami financial distress. Hal ini dapat terjadi karena kepemilikan institusional mayoritas yang ada di dalam perusahaan hanya dimiliki oleh beberapa pihak intansi, selain itu terdapat juga perusahaan yang tidak memiliki saham instiusional didalam perusahaannya

\section{Pengaruh Komite Audit terhadap Financial Distress}

Hasil penelitian berdasarkan tabel 3 menunjukkan $\mathrm{H} 4$ yang menyatakan komite audit tidak berpengaruh negatif terhadap prediksi financial distress ditolak. Hal tersebut bertentangan dengan teori agensi yang menyatakan bahwa rapat atau pertemuan komite audit dapat mengurangi permasalahan kondisi keuangan perusahaan. Pertemuan yang tidak konsisten atau kurangnya pertemuan yang dilakukan oleh komite audit dapat menjadi faktor penyebab pertemuan atau rapat komite audit tidak dapat mengurangi intensitas perusahaan mengalami financial distress. Hasil dari penelitian ini tidak konsisten dengan hasil penelitian yang dilakukan oleh Nuresa \& Hadiprajitno (2013) yang menyatakan bahwa komite audit berpengaruh negatif terhadap financial distress.

\section{Pengaruh Leverage terhadap Fianacial Distress dimoderasi oleh Profitabilitas}

Hasil pengujian yang disajikan pada tabel 3 menunjukkan bahwa $\mathrm{H}_{5}$ yang menyatakan bahwa profitabilitas mampu memoderasi pengaruh leverage terhadap prediksi financial distress diterima. hal ini dapat terjadi karena kinerja manajemen dalam menjalankan operasional baik, sehingga laba yang diperolah sesuai dengan target yang telah ditentukan sebelumnya. Dari laba yang telah dihasilkan oleh perusahaan ini maka laba tersebut dapat digunakan untuk membayar kewajiban jangka panjang mauapun jangka pendek (leverage) beserta bunga yang telah ditentukan, sehingga kemungkinan perusahaan akan mengalami financial distress akan semakin kecil. Hal ini sejalan dengan Agency Theory bahwa kegiatan operasional merupakan hal yang harus dilakukan oleh agent, apabila agent tepat dalam mengambil keputusan sehingga produk yang dihasilkan oleh perusahaan akan terjual dalam kapasitas tinggi sehingga laba yang diperoleh pun juga tinggi.

\section{Pengaruh Rasio Pasar terhadap Financial Distress dimoderasi oleh Profitabilitas}

Hasil pengujian yang disajikan pada tabel 3 menunjukkan bahwa $\mathrm{H}_{6}$ yang menyatakan bahwa profitabilitas tidak mampu memoderasi pengaruh rasio pasar terhadap prediksi financial distress. Profitabilitas dalam penelitian ini tidak mampu memoderasi pengaruh rasio pasar terhadap financial distress. Hasil dari penelitian ini tidak sejalur dengan teory agency dimana manajer sebagai pihak dalam menentukan strategi atau pengambil keputusan dalam mengasilkan laba agar EPS yang diterbitkan tinggi belum tidak cukup untuk mengurangi intensitas perusahaan mengalami financial distress, hal tersebut mungkin dikarenakan terdapat faktor lain yang dipertimbangkan oleh pihak investor dalam menangkap sinyal yang diberikan oleh perusahaan.

\section{Pengaruh Kepemilikan Institusional terhadap Financial Distress dimoderasi oleh Profitabilitas}

Hasil pengujian yang disajikan pada tabel 3 menunjukkan bahwa $\mathrm{H}_{7}$ yang menyatakan bahwa profitabilitas tidak mampu memoderasi pengaruh kepemilikan institusional terhadap prediksi financial distress. Profitabilitas tidak mampu memoderasi kepemilikan institusional yang tergolong tinggi ini persebarannya tidak merata sehingga pengendalian yang dilakukan masih 
kurang efektif, sehingga kinerja manajemen dalam mengambil keputusan dapat menyimpang dari kinerja manajemen yang sebenarnya, atau dapat dikatakan pengambilan keputusan yang dilakukan oleh manajemen cenderung mengntungkan dirinya sendiri.

\section{Pengaruh Komite Audit terhadap Financial Distress dimoderasi oleh Profitabilitas}

Hasil pengujian yang disajikan pada tabel 3 menunjukkan bahwa $\mathrm{H}_{8}$ yang menyatakan bahwa profitabilitas tidak mampu memoderasi pengaruh komite audit terhadap prediksi financial distress. Profitabilitas dalam hal ini juga menjadi tanggung jawab agen terhadap principal, namun dalam penelitian ini perusahaan yang memiliki profitabilitas tinggi belum tentu memiliki komite audit yang efektif dalam menjalankan tugasnya yaitu mengadakan rapat yang teratur agar keputusan yang diambil dapat mengurangi masalah dan menjauhkan perusahaan dalam kondisi financial distress.

\section{SIMPULAN}

Simpulan dari penelitian ini yaitu dari delapan hipotesis yang dirumuskan, 6 hipotesis diantaranya ditolak, sedangkan 2 hipotesis sisanya diterima. Hipotesis yang ditolak dalam penelitian ini adalah variabel leverage, rasio pasar, komite audit, rasio pasar yang dimoderasi oleh profitabilitas, dimoderasi rasio pasar yang dimoderasi oleh profitabilitas,kepemilikan institutional dimoderasi oleh profitabilitas, dan komite audit yang dimoderasi oleh profitabilitas. Sedangkan variabel yang diterima dalam penelitian ini adalah kepemilikan institusional, dan leverage dimoderasi oleh profitabilitas. Keterbatasan penelitian ini yaitu jumlah perusahaan yag mengalami distress dan tidak distress tidak sebanding sehingga untuk penelitian selanjutnya diharapkan menggunakan sektor sektor lain seperti sektor atau agrikultur.

\section{DAFTAR PUSTAKA}

Agusti, C. P. 2013. Analisis Faktor Yang Mempengaruhi Kemungkinan Terjadinya Financial Distress. Skripsi. Universitas Diponegoro.

Andre, O. 2013. Pengaruh Profitabilitas, Likuiditas dan Leverage dalam Memprediksi Financial Distress (Studi Empiris pada Perusahaan Aneka Industri yang Terdaftar di BEI). Jurnal Akuntansi. 1(1):1-23.

Bodroastuti, T. 2009. Pengaruh Struktur Corporate Governance terhadap Financial Distress The Influence of Corporate Governance Structure to Financial Distress. Available at https://media.neliti.com/media/publications/36583-ID-pengaruh-struktur-corporategovernance-terhadap-financial-distress.pdf. Diunduh pada 3 Januari 2019

Brahmana, R. K. 2006. Identfying Financial Distress Condition in Indonesia Manufacture Industry. Birmingham Business School. 1-19.

Curry, K., \& Banjarnahor, E. 2018. Financial Distress Pada Perusahaan Sektor Properti Go. Prosiding. Disajikan dalam Seminar Nasional Pakar.

Fathonah, A. N. 2016. Pengaruh Penerapan Good Corporate Governance. Jurnal Ilmiah Akuntansi, $1(2): 133-150$.

Fitriyah, I., \& Hariyati. 2013. Ida Fitriyah dan Hariyati; The Effect of Financial Ratio. Jurnal Ilmu Manajemen. 1.

Hanifah, O. E., \& Purwanto, A. 2013. Pengaruh Struktur Corporate Governance Dan Financial Indicators Terhadap Kondisi Financial. Diponegoro Jurnal of Accounting. 2: 1-15.

Helena, S., \& Saifi, M. 2016. Pengaruh Corporate Governance Terhadap Financial Distress (Studi Pada Perusahaan Transportasi Yang Terdaftar Di Bursa Efek Indonesia Periode 2013-2016 ). Jurnal Administrasi Bisnis. 60 (2) :143-152.

Hidayat, M. A., \& Meiranto, W. 2014. Prediksi Financial Distress Perusahaan Manufaktur Di Indonesia. Diponegoro Jurnal of Accounting. 3: 1-11.

Jensen, C. M., \& Meckling, H. W. 1976. Theory Of The Firm : Managerial Behavior, Agency Costs And Ownership Structure. Journal of Financial Economics. 3 : 305-360.

Lisiantara, G. A., \& Febrina, L. 2018. Growth Sebagai Preditor Financial Distress ( Studi Empiris 
Risma Wilujeng dan Agung Yulianto : Determinan Financial Distress Dengan Profitabilitas Sebagai Variabel Moderasi

Pada Perusahaan Manufaktur Yang Terdaftar Di Bursa Efek Indonesia Tahun 2013-2016 ). Prosiding. Universitas Stikubank Semarang

Nuresa, A., \& Hadiprajitno, B. 2013. Pengaruh Efektivitas Komite Audit Terhadap Financial. Diponegoro Jurnal of Accounting. 2: 1-10.

Oz, I. O. 2016. A theoretical approach to financial distress prediction modeling. Emeraldinsight. 43: $212-230$.

Platt, H. D., \& Platt, M. B. 2002. Predicting Corporate Financial Distress : Reflections on ChoiceBased Sample Bias. Jurnal of Economics and Finance. 26 (2):184-199.

Prasetyo, R. A., \& Fachrurrozie. (2016). Analysis of Factors Effecting on The Probability of Financial Distress. Accounting Analsis Journal. 5 (4): 370-380.

Putri, N. W. K. A. P., \& Merkusiwati, N. K. L. A. 2014. Pengaruh Mekanisme Corporate Governance, Likuiditas, Leverage, Dan Ukuran Perusahaan Pada Financial Distress. EJurnal Akuntansi Universitas Udayana. 1: 93-106.

Radifan, R. N., \& Yuyetta, E. N. A. 2015. Analisis Pengaruh Mekanisme Good Corporate Governance terhadap Kemungkinan Financial Distress. Diponegoro Jurnal of Accounting. 4: $1-11$.

Septivani, R., \& Agoes, S. 2014. Septivani dan Agoes: Pengaruh Kinerja Keuangan Perusahaan, Corporate Governance dan Intellectual Capital terhadap Kemungkinan Terjadinya Financial Distress (Studi Empiris pada Perushaan Non Jasa Keuangan Di Bursa Efek Indonesia). Jurnal Fakultas Ekonomi Univeritas Bakrie Dan Fakultas Universitas Tarumanegara. V (01):161176.

Simanjuntak, C., Titik, F., \& Aminah, W. 2017. Pengaruh Rasio Keuangan Terhadap Financial Distress ( Studi Pada Perusahaan Transportasi Yang Terdaftar Di The Influence Of Financial Ratio To Financial Distress ( Study In Transportation Companies On Listed In Indonesia Stock Exchange During 2011-2015 ). E-Proceeding of Management. 4 (2):1580-1587.

Whitaker, B. 1999. The Early Stages of Financial Distress. Jurnal of Economics and Finance. 23: $123-133$.

Widarjo, W., \& Setiawan, D. 2009. Pengaruh Rasio Keuangan Terhadap Kondisi Financial Distress Perusahaan Otomotif. Jurnal Bisnis Dan Akuntansi. 11 (2):107-119.

Widhiari, N. L. M. A., \& Merkusiwati, N. K. L. A. 2015. Pengaruh Rasio Likuiditas, Leverage, Operating Capacity, Dan Sales Growth Terhadap Financial Distress. E-Jurnal Akuntansi Universitas Udayana. 2: 456-469.

Yudadibrata, H. B. N., \& Soenarno, Y. N. 2016. Analisis Rasio Keuangan Dan Struktur Kepemilikan Perusahaan Dalam Memprediksi Kesulitan Keuangan: Sebuah Riset Empiris Pada Perusahaan Nonkeuangan Yang Terdaftar di Bursa Efek Indonesia. Jurnal Akuntansi. 1: $83-115$. 